\title{
Chromate Reduction in Serratia marcescens Isolated from Tannery Effluent and Potential Application for Bioremediation of Chromate Pollution
}

\author{
M.A. Mondaca ${ }^{1, *}$, V. Campos ${ }^{1}$, R. Moraga ${ }^{1}$, and C.A. Zaror $^{2}$ \\ ${ }^{1}$ Microbiology Department; ${ }^{2}$ Chemical Engineering Department, University of \\ Concepción, P.O. Box 152-C, Correo 3, Concepción, Chile
}

Received November 10, 2001; Revised January 25, 2002; Accepted February 1, 2002; Published April 9, 2002

\begin{abstract}
Pollution of aquatic systems by heavy metals has resulted in increasing environmental concern because they cannot be biodegraded. One metal that gives reason for concern due to its toxicity is chromium. $\mathrm{Cr}(\mathrm{VI})$ and $\mathrm{Cr}(\mathrm{III})$ are the principal forms of chromium found in natural waters. A chromate-resistant strain of the bacterium $S$. marcescens was isolated from tannery effluent. The strain was able to reduce $\mathrm{Cr}(\mathrm{VI})$ to $\mathrm{Cr}(\mathrm{III})$, and about $80 \%$ of chromate was removed from the medium. The reduction seems to occur on the cell surface. Transmission electron microscopic examination of cells revealed that particles were deposited on the outside of bacterial cells. A stable biofilm was formed in less than $10 \mathrm{~h}$, reaching around $10^{10} \mathrm{cfu}$ attached per milligram of activated carbon. These findings demonstrate that immobilized $S$. marcescens might be used in industrial waste treatment processes.
\end{abstract}

KEY WORDS: chromate pollution, chromate reduction, biofilm

DOMAINS: terrestrial environmental toxicology, environmental management and policy, ecosystems and communities

\section{INTRODUCTION}

Widespread pollution by heavy metals has important consequences for human health and environmental quality. Manufacturing processes and domestic wastewater are major sources of chromium contamination[1]. $\mathrm{Cr}(\mathrm{VI})$ and $\mathrm{Cr}(\mathrm{III})$ are the principal forms of chromium found in natural waters. $\mathrm{Cr}(\mathrm{VI})$ is a highly soluble and toxic agent that is also mutagenic and carcinogenic, whereas $\mathrm{Cr}$ (III) is much less toxic and tends to form insoluble hydroxides[2]. Therefore, reduction of $\mathrm{Cr}(\mathrm{VI})$ to $\mathrm{Cr}(\mathrm{III})$ is a potentially useful process for the remediation of chromiumcontaminated waters and waste streams. A wide variety of microorganisms can enzymatically reduce $\mathrm{Cr}(\mathrm{VI})$ to $\mathrm{Cr}(\mathrm{III})[3]$. 
Chromate-resistant Serratia marcescens bacteria, isolated from a tannery effluent, has been shown to present chromate-reduction activity and can grow in the presence of a wide range of industrial contaminants. The reduction of chromate is a potentially useful process for the remediation of chromium-contaminated waters. The method most often applied to metal removal is the use of cells immobilized as a biofilm on inert supports[4]. The formation of biofilms can be considered as a development cycle. It begins when free-swimming (planktonic) bacteria recognize a surface and firmly attach themselves to it. Subsequently, the attached cells grow and divide, and at the same time recruit additional planktonic cells that attach to the cells already on the surface[5]. Bacterial adhesion is not only of importance in microbial ecology, but also in biotechnology, biofouling, and wastewater treatment. The ability of a bacterium to interact with a given surface is known to be governed by particular molecules or structures on the outer surface of the cell. These may be proteins or lipopolysaccharides in the outer membrane, proteinaceous appendages such as fimbriae or flagella, or a complex carbohydrate in the form of extracellular capsules[6]. Understanding the fundamental processes contributing to biofilm formation is beneficial to anyone involved with natural or industrial systems, where biofilms may play a significant role in determining variables such as bulk water quality, toxic compound biodegradation, or product quality.

The objective of this work was to assess the chromate-reductase activity of S. marcescens isolated from tannery effluent and its ability to attach to an inert surface.

\section{METHODOLOGY}

\section{Bacteria Strain}

A chromate-resistant bacterial strain was isolated from a tannery effluent (Concepción, Chile). The strain was identified as $S$. marcescens using a rapid identification kit (EM-Ident E, SensIdent, Merck Darmstdat, Germany). An overnight culture was diluted in nutrient broth or KSN medium with various concentrations of chromate, and incubation proceeded at $30^{\circ} \mathrm{C}$ for $24 \mathrm{~h}$ under aerobic conditions. Growth was assayed by measuring turbidity with a spectrophotometer at $660 \mathrm{~nm}$ [7].

\section{Assay of Chromate-Reduction Activity}

Samples were withdrawn at different times and centrifuged at 3,000 rpm for 5 min prior to analysis. $\mathrm{Cr}(\mathrm{VI})$ and $\mathrm{Cr}(\mathrm{III})$ were determined by high pressure liquid chromatography and on-line flame absorption atomic spectroscopy (HPLC-FAAS)[8].

\section{Hydrophobicity Test}

Bacterial adherence was tested using the methods described by Rosenberg et al.[9]. Bacteria suspended in an aqueous phase were mixed with toluene and spun into a vortex. The optical density of the aqueous phase was measured before and after mixing. Results were expressed as the percentage of bacteria excluded from the aqueous phase.

\section{Attachment of Strain to Activated Carbon (Biofilm Formation)}

Cells were cultured until an exponential phase was achieved. Activated carbon, washed with sterile distilled water, was added to the nutrient broth in proportion 5:100 (w/v) and then inoculated with a small aliquot of bacterial inoculum in order to obtain approximately $10^{5}$ $\mathrm{CFU} / \mathrm{ml}$. Incubation was performed at room temperature with constant low-speed shaking. After 3,24 , and $72 \mathrm{~h}$ of incubation, duplicated activated carbon samples were washed with distilled water. 


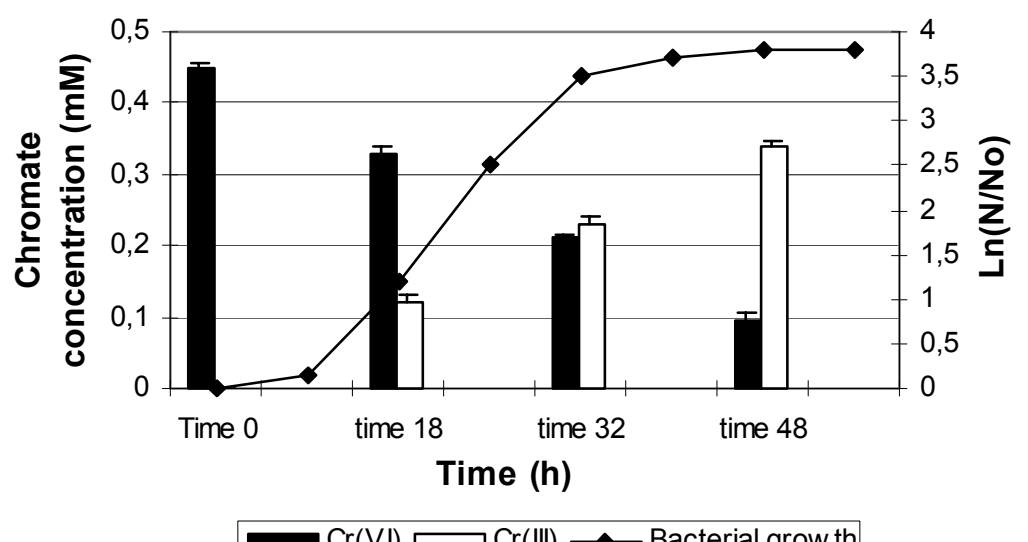

FIGURE 1. Reduction of chromate by $S$. marcescens cell culture.

\section{Scanning Electron Microscopy (SEM)}

Samples of activated carbon were fixed with $2.5 \%$ glutaraldehyde. Samples were critical-point dried with $\mathrm{CO}_{2}$ and coated with gold (S150 sputter coater). These were observed with an SEM (ETEC Company, autoscan) operating at an accelerating voltage of $20 \mathrm{kV}$.

\section{RESULTS AND DISCUSSION}

Fig. 1 shows the results of $S$. marcescens cells cultured aerobically in KSC medium containing $0.5 \mathrm{mM}$ chromate. As the cell concentration increases, chromate concentration decreases. $S$. marcescens was able to reduce $\mathrm{Cr}(\mathrm{VI})$; about $80 \%$ of $\mathrm{Cr}(\mathrm{VI})$ was reduced to $\mathrm{Cr}(\mathrm{III})$ within $48 \mathrm{~h}$. Cell-free KSC media did not show any reduction of chromate.

Several methods have been proposed to determine hydrophobicity. In the study, we used the BATH test, in which the migration of the bacteria from the aqueous phase depended upon their ability to adhere to the organic phase. The strain gave higher hydrophobicity values $(67 \%)$, and hydrophobic cells adhered in a greater extent than hydrophilic cells.

A solution containing $105 \mathrm{CFU} / \mathrm{ml}$ of exponential phase S. marcescens was cultured in the presence of activated carbon (Filtrasorb 400). The colonization properties of S. marcescens were quantified on the surfaces of activated carbon. As shown in Fig. 2, this strain established a stable biofilm containing about 109 (UFC/g active carbon) in $24 \mathrm{~h}$.

SEM showed a stable biofilm on the carbon surface after $3 \mathrm{~h}$ culture and revealed the presence of copious numbers of fibrillar structures, closely associated with the cells, looking like the particular fimbriae described by the Olsen group and designated as curly[10]. Each bacterium was anchored to the carbon surface by means of fibrils in order to bridge the space between the two bodies and allow attachment of the bacterium (Figs. 3A, 3B, and 3C). After $72 \mathrm{~h}$ incubation, the attached bacteria excreted extracellular polysaccharides that served as the matrix for the biofilms and covering sessile cells[11]. Similar results were obtained when using water-insoluble polymers as support for a biofilm of $S$. marcescens (Figs. 4A, 4B, and 4C).

Fig. 5 shows chromate reduction by immobilized $S$. marcescens on activated carbon. About $86 \%$ of chromate was removed from the medium. 


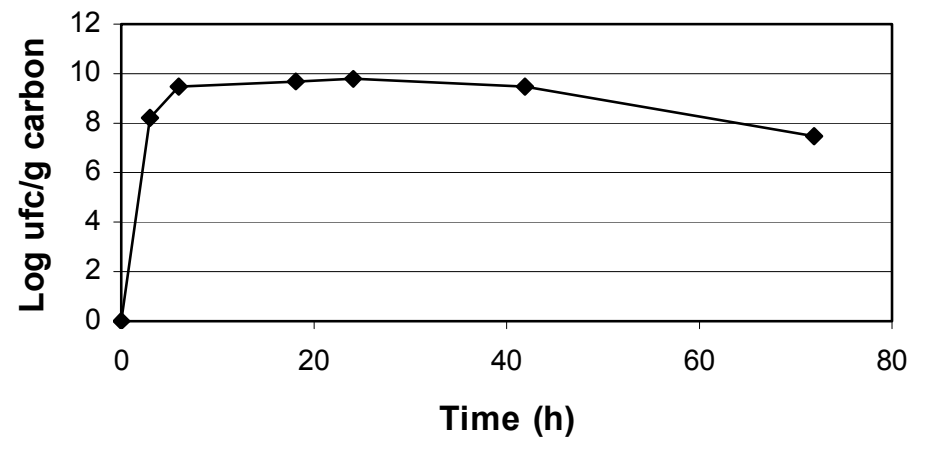

FIGURE 2. Growth of S. Marcescens attached on activated carbon.
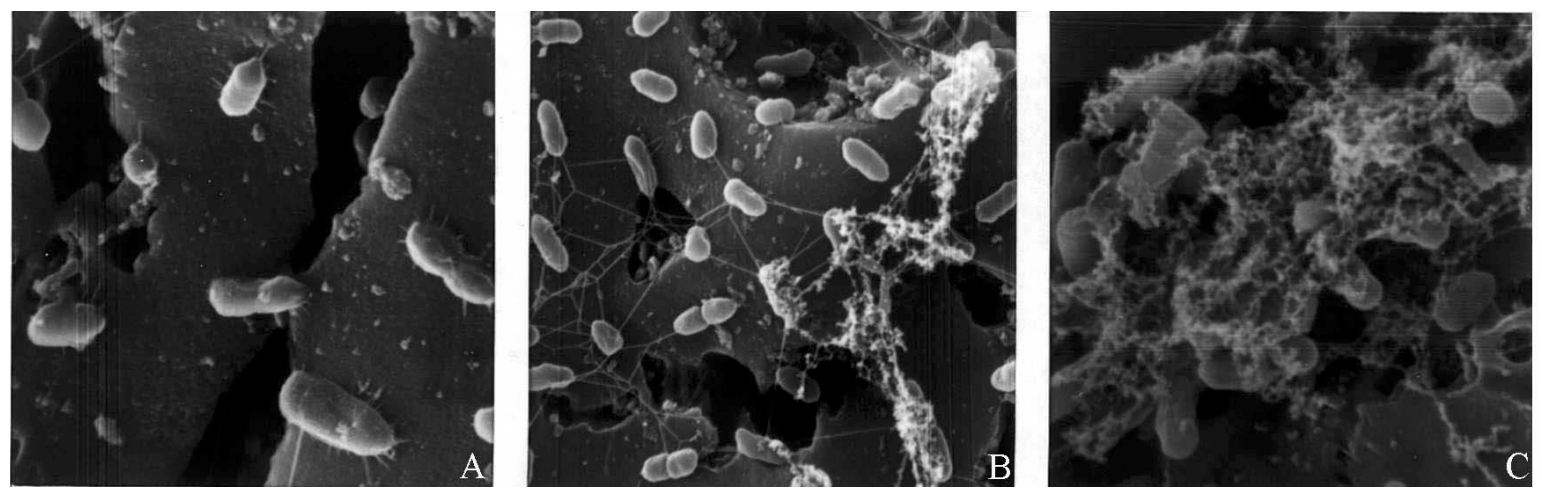

FIGURE 3. Biofilm formation of S. marcescens on activated carbon. (a) $3 \mathrm{~h}$ (b) 24 (c) $72 \mathrm{~h}$.
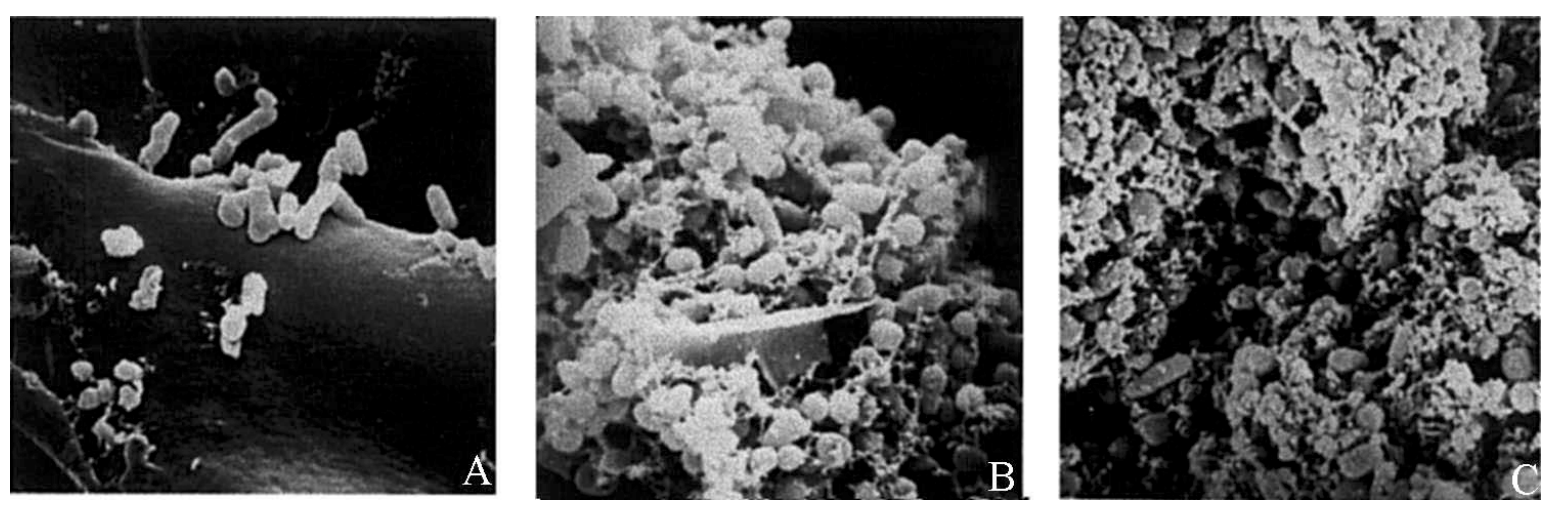

FIGURE 4. Biofilm formation of S. marcescens on synthetic polymer. (a) $24 \mathrm{~h}$ (b) $72 \mathrm{~h}$ (c) $96 \mathrm{~h}$. 


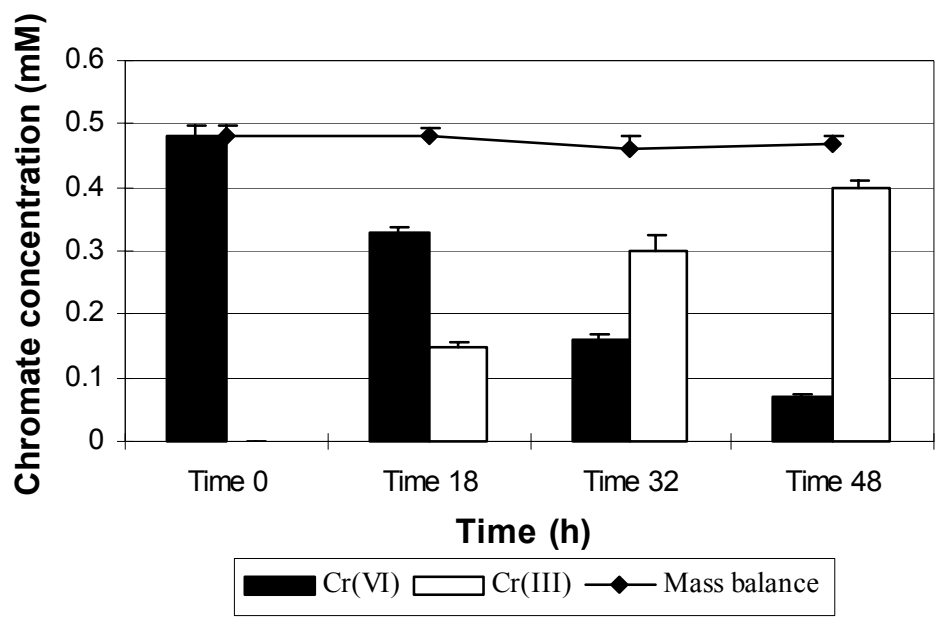

FIGURE 5. Chromium (VI) reduction by S. marcescens immobilized on activated carbon with initial $0.5 \mathrm{mM}$ potassium chromate at $30^{\circ} \mathrm{C}$.

\section{CONCLUSIONS}

S. marcescens is able to reduce $\mathrm{Cr}$ (VI) to $\mathrm{Cr}$ (III). It firmly attaches to activated carbon particles and forms a stable biofilm. These findings demonstrate the possibility that immobilized $S$. marcescens might be used in bioremediation of $\mathrm{Cr}(\mathrm{VI})$-contaminated industrial effluent.

\section{ACKNOWLEDGMENTS}

This research was fully supported by the Dirección de Investigación, Universidad de Concepción (Project No. 99.036.016-1.0).

\section{REFERENCES}

1. Myers, C., Carstens, B., Antholine, W., and Myers, J. (2000) Chromium (VI) reductase activity is associated with the cytoplasmic membrane of anaerobically grown Shewanella putrefaciens MR-1. J. Appl. Microbiol. 88, 98-106.

2. Richards, F. and Bourg, C. (1991) Aqueous geochemistry of chromium: a review. Water Res. 25, 807-816.

3. Lovley, D. (1993) Dissimilatory metal reduction. Annu. Rev. Microbiol. 47, 263-290.

4. $\quad$ Costerton, J.W., Lewandowski, Z., DeBeer, D., Caldwell, D., Korber, D., and James, G. (1994) Biofilms: the customised microniche. J. Bacteriol. 176, 2137-2142.

5. Cunliffe, D., Smart, C., and Vulfson, E. (1999) Bacterial adhesion at synthetic surfaces. Appl. Environ. Microbiol. 65, 4995-5002.

6. Schneider, R.P. and Marshall, K.C. (1994) Retention of the gram-negative bacterium SW8 on surface-effects of microbial physiology, substratum nature and conditioning films. Colloids Surfaces B Biointerfaces 2, 387-396.

7. Wang, P.C., Mori, T., Komori, K., Sasatsu, M., Toda, K., and Ohtake, H. (1989) Isolation and characterization of an Enterobacter cloacae strain that reduces hexavalent chromium under anaerobic conditions. Appl. Environ. Microbiol. 55, 1665-1669.

8. Posta, J., Berndt, H., Lou, S., and Schaldach, G. (1993) High-performance flow flame atomic absorption spectrometry for automated on line separation and determination of $\mathrm{Cr}(\mathrm{III}) / \mathrm{Cr}(\mathrm{VI})$ and preconcentration of Cr(VI). Anal. Chem. 65, 2590-2595.

9. Rosenberg, M., Gutnick, D., and Rosenberg, E. (1980) Adherence of bacteria to hydrocarbons: a simple method for measuring cell-surface hydrophobicity. FEMS Microbiol. Lett. 9, 29-33.

10. Olsen, A., Jonsson, A., and Normar, S. (1989) Fibronectin binding mediated by a novel class of surface organelles on Escherichia coli. Nature 338, 652-655.

11. Allison, D.G. and Sutherland, L.W. (1987) The role of exopolysaccharides in adhesion of freshwater bacteria. J. Gen. Microbiol. 133, 1319-1327. 


\section{This article should be referenced as follows:}

Mondaca, M.A., Campos, V., Moraga, R., and Zaror, C.A.. (2002) Chromate reduction in Serratia marcescens isolated from tannery effluent and potential application for bioremediation of chromate pollution. In The International Conference on Environmental Concerns and Emerging Abatement Technologies 2001: Collection of Short Communications. TheScientificWorldJOURNAL 2, 972-977.

\section{Handling Editor:}

Nicholas Lepp, Associate Editor for Terrestrial Environmental Toxicology — a domain of TheScientificWorldJOURNAL. 

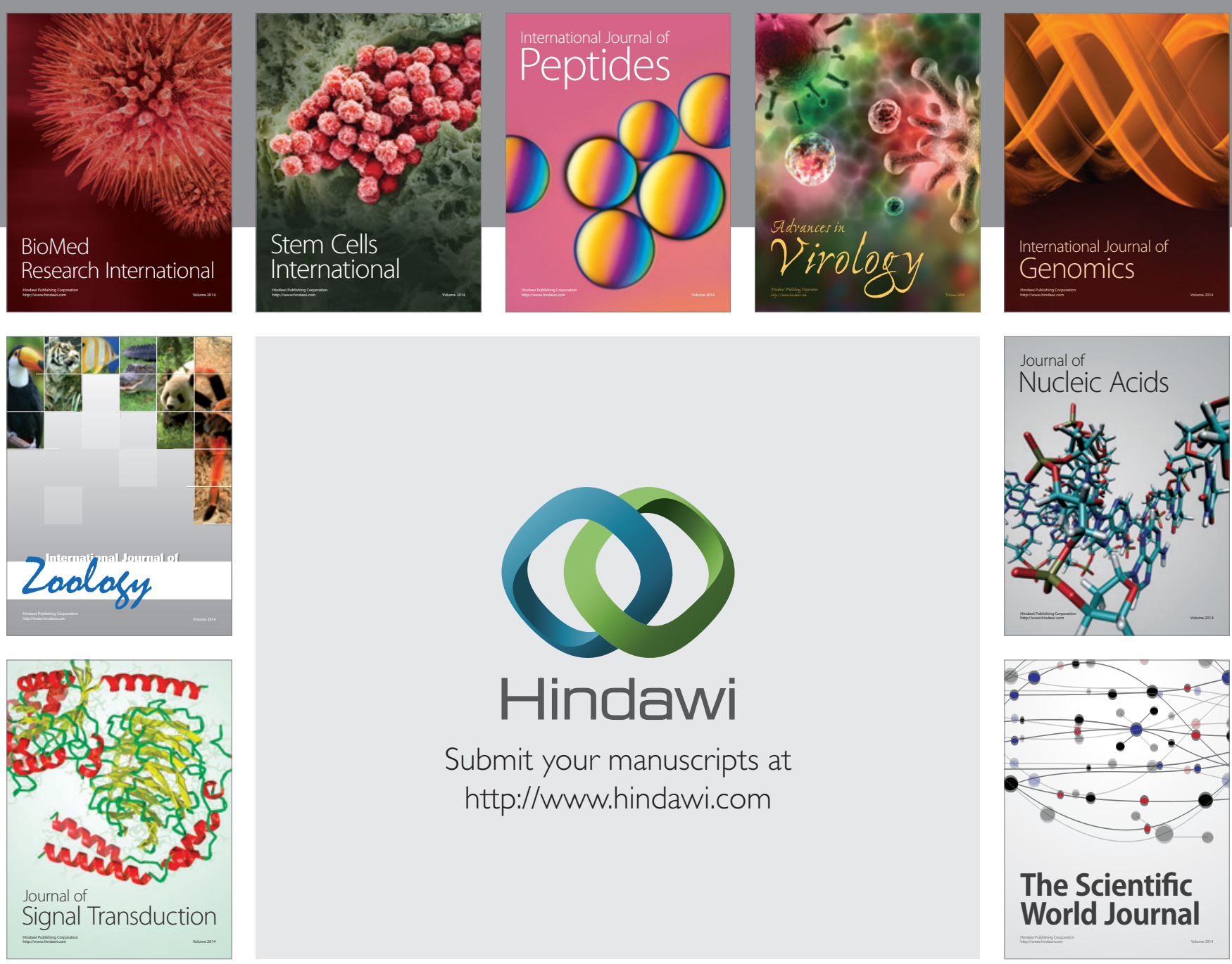

Submit your manuscripts at

http://www.hindawi.com
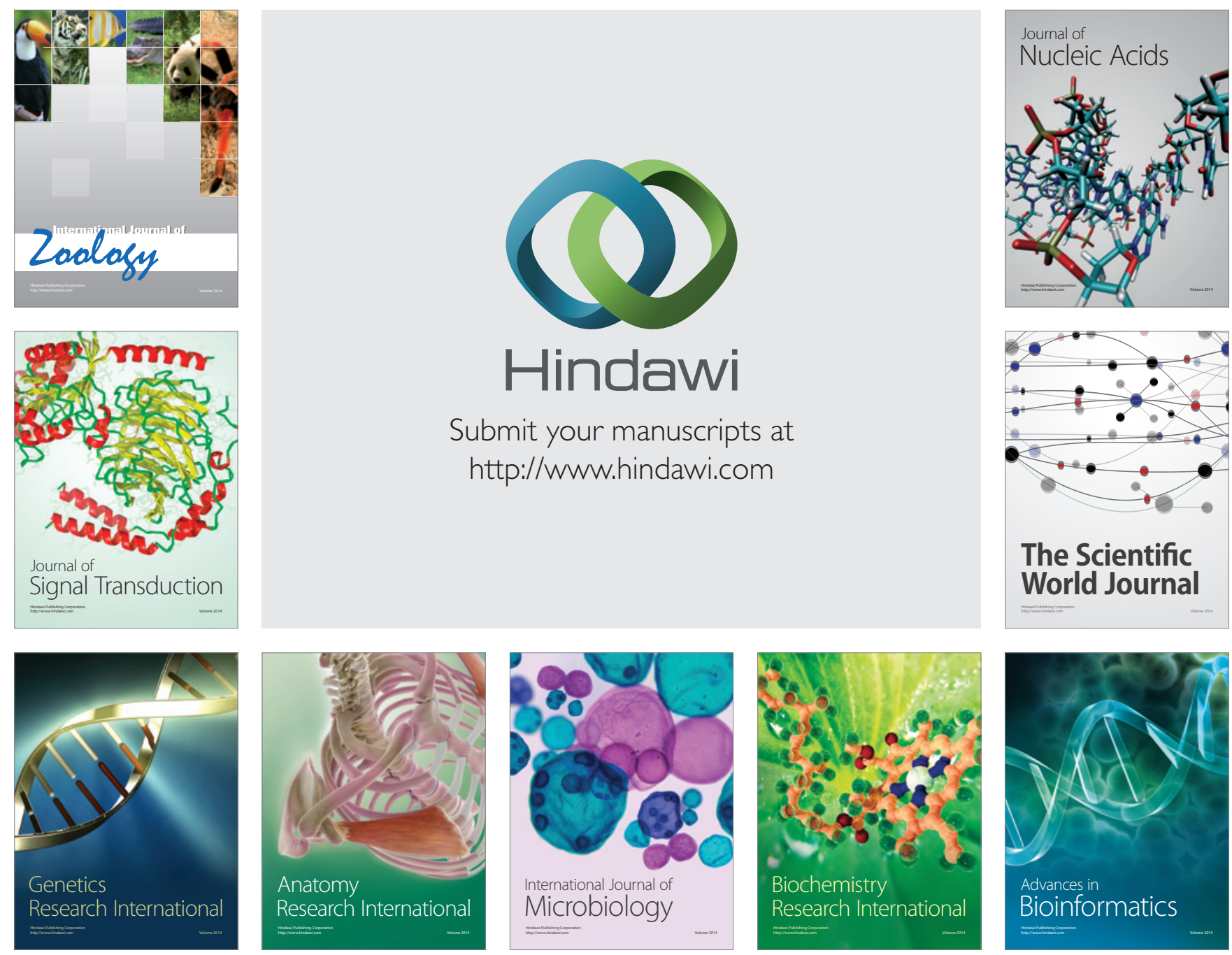

The Scientific World Journal
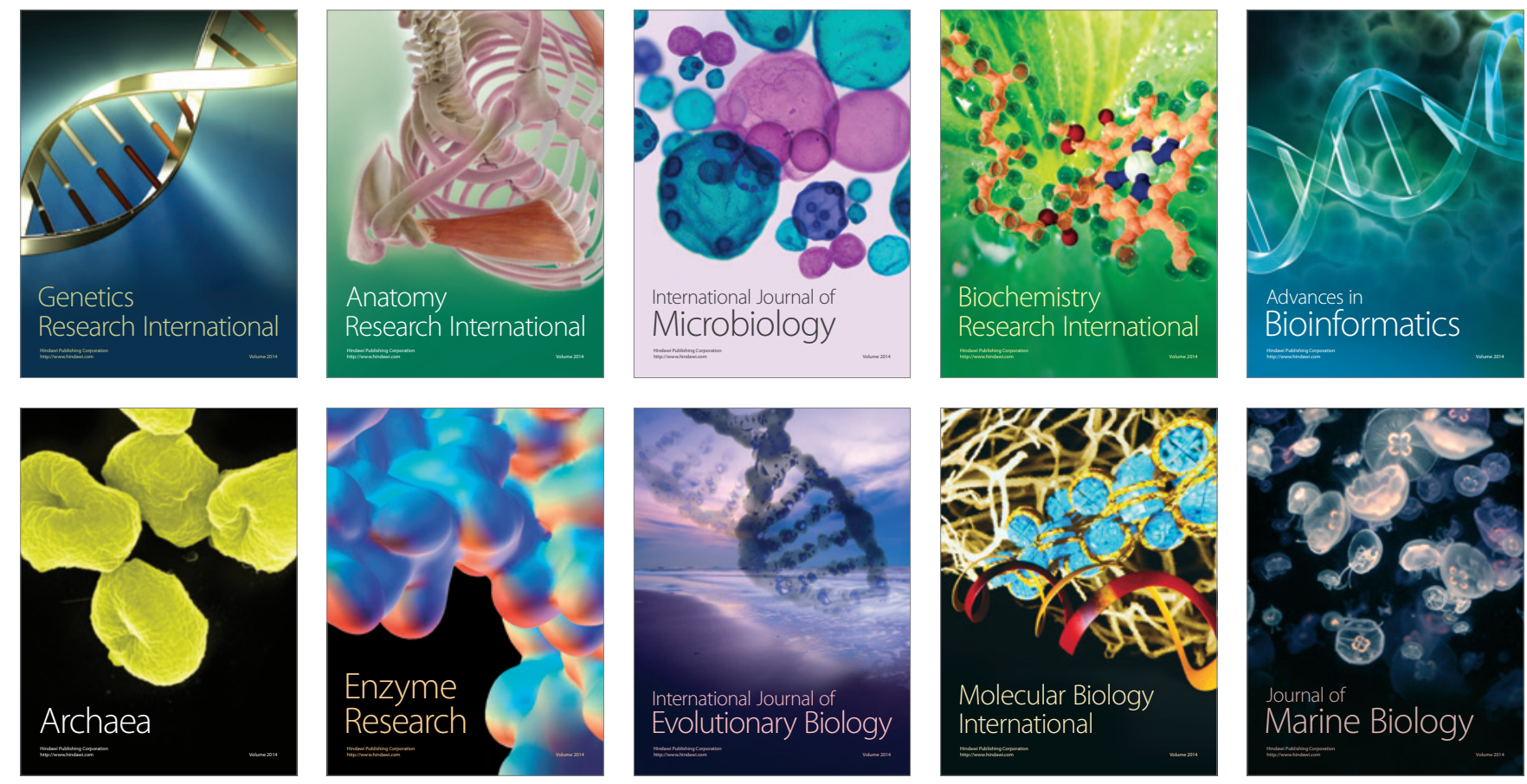